\title{
Does Stock Options Plan Really Matter on the Malaysian Firm Performance?
}

\author{
Zuriadah Ismail $^{1}$, Everton Dockery ${ }^{2} \&$ Anis Suriati Ahmad ${ }^{3}$ \\ ${ }^{1,3}$ Faculty of Management and Economics, Universiti Pendidikan Sultan Idris, Malaysia \\ ${ }^{2}$ Portsmouth Business School, University of Portmouth, United Kingdom \\ Email: zuriadah@fpe.upsi.edu.my \\ DOI: https://doi.org/10.37134/jcit.vol7.10.2017
}

\begin{abstract}
This paper examines the effect of stock options plan on firm performance. By using a multivariate regression analysis on 58 Malaysian listed firms with stock option plan, the main finding shows that granting stock option plans do not entirely lead to improvements over firm performance in Malaysia. From this result may spur a debate about the role stock option plans play in enhancing firm performance as in the few years that stock options have been in use in Malaysia, stock option plans gained popularity. But at the same time manipulation in accounting measures such as creative accounting and earnings management, has led the public to question the practicality in adopting stock option plans at least for reducing agency problems.
\end{abstract}

Keywords Stock Option plan, Firm performance

\section{Introduction}

Theoretically, stock option plan are designed based on the principle that the agency problems can be alleviated if the firm has clear lines of separation between ownership and control (Jensen and Meckling (1976). The literature in this area mostly examine whether compensation plans are effectively designed for achieving specific goals. A part of the goal is to motivate executives to increase shareholders' wealth. In short, stock option plans are viewed as an effective method to achieve this objective and for aligning the interest of principal (i.e. shareholders) and agent (i.e. managers). In the recent main stream of literature highlights the relation between stock option plans and their wealth-increasing effect. The general consensus is that stock options create a conflict between shareholders and managers, particularly with respect to managerial quality and effort to increase the firms performance which is a common measure of firm value observed by shareholders. The capability of executive employee to influence the individual share price performance is more direct than the non-executive employees. One of which could be that management have better control over information releases.

As a result, management are considered to receive more benefits due to the effects of incentives even when stock prices fall. On occasions executives tends to be overly cautious with the incentive effects that stock option plans bring, particularly when making decisions that directly benefits their own self-interests without damaging shareholders' wealth. As this suggests, executives tend to be risk-takers, engaging in high profitable projects while at the same time they become less risk-taker for increasing firm value (Defusso, Johnson and Zorn, 1990; Cohen,Hall and Viceira, 2000 and Rajgopal and Shevlin, 2002). Thus the generosity of shareholders which is reflected in equity compensation pay may result in a 
marginal loss by way of the dilution effects (Ikaheimo, Kjellman, Holmberg and Jussila, 2004). Therefore, shareholders accept stock option plans unfavourably when the plan adoption produces decreasing-wealth effects.

\section{Literature Review}

With reference to the long-run firm performance and the effects of stock option plans, the reported empirical evidence is generally mixed, while the use of executive stock options as an instrument to improve long-term firm performance is reported to only have mild effect on firm value. A number of studies suggest that stock option plan may enhance firm value. For example, Sesil, Kroumova, Blasi and Kruse (2002) report that U.S. corporations that provide stock options are likely to enhance productivity, accounting performance and market returns, even though it does not automatically improve the outcome. Hillegeist and Penalva (2004) also report the effect of stock option plans on performance using a variety of performance measures target groups during the period 1996 to 1999 and find a positive relationship across the sample. Likewise Hassan and Hoshino (2007) measured the effects of stock option plans for 1600 firms for the period 1997 to 2004 with respect to enhancing corporate value and found that operating performance and stock market returns increased after the plans announcement. The positive effect of stock option plans on long-term performance is also found in European market studies such as Duffhues, Kabir Mertens and Roosenboom (2003), Duffhues and Kabir (2008) and Ozkan (2009). Duffhues et al. (2003) and Duffhues and Kabir (2008) investigate the performance-enhancing effects of stock options using Dutch market data as a proxy by return of asset (ROA) and return on equity (ROE) and report a positive association between the variables. Their findings are consistent with Ozkan (2009) who used U.K. data to study the long-term incentive effects of stock option plans. Their findings suggest a strong association between stock return, ROA and stock option plans. However, Smith and Swan (2008) provide more robust results on the positive effects. Their findings indicate that the combination of the level of pay (that is, equity and cash basis) create an incentive value for managers to enhance firm performance. They also report that stock option plans are not the main method at the disposal of owners to induce performance -enhancing effects.

Quite a few studies have attempted to explain unsuccessful stories about the performance enhancing effect that stock option plans could generate in long-term. For example, Sanders and Hambrick (2007) claim that stock option plans result in extreme firm performance. In brief, they suggest that a large fraction of stock options allocated to top executive employees could lead to big losses rather than gains. This is possible, particularly when executives are motivated to be more of a risk-taker. Similarly, Obiyathulla et al. (2009) using Malaysian data investigate the effect of stock option plans on long-term firm performance and found that accounting profits declined three years before and after the implementation of stock option plans. Bulan, Sanyal and Yan (2010) found similar effects which indicate that stock option plans do not have productivity-increasing effects and thus fail to influence accounting performance. Triki and Ureche-Rangau (2012) examined the long-term relationship between stock options and firm value using French data and report weak direction for both variables as measured by the industry-adjusted ROA, ROE and 
abnormal returns. This finding suggests that stock option plans fail to create the incentive for value-increasing, even though it is widely applied in the French companies. Arguably, the extent to which stock option plans can generates benefits for shareholders and managers with the ascribed effects does depend on the harmonisation of their interests. This is apparent, since both parties might capture the benefits that stock option plans bring, even though part of the study included mixed results. In addition, there is also evidence which indicate that stock option plans provide signalling effects to the market in the short-term and share prices could be expected to react according to the approval of the option plans (Tehranian and Waegelein, 1985). While for the long-term effect on corporate performance, it is likely to generate mixed results, which as earlier discussed is as part of the literature which report both positive and negative effects from the use of stock options.

\section{Data and Research Methodology}

One of the main goals of this study is to determine the effect of Malaysia's stock option plans on firm performance. Therefore, in this context, a large number in the economics and finance literature use a standard regression analysis. In this respect to selected sample firms, this study excludes the Malaysian firm without stock options plan that established before 2000. Most of firms are called as "missing data" since the detailed data was not available. While for comparator groups, this study also uses the Bursa Malaysia listing circulars to construct groups and this includes firm with employee stock option plans and executive stock option plans only and combination between executive and employee stock option (broad-based stock options). All the comparison firms have similar industry and size. As detailed and after identified the population on the firm with stock option programs, the process of selection of the final sample as follows:

\begin{tabular}{|l|c|}
\hline Descriptions & Number of Firms \\
\hline $\begin{array}{l}\text { Firms with stock option programs as listing in } \\
\text { Companies announcements. }\end{array}$ & 177 \\
\hline After deduction of missing data & 25 \\
\hline $\begin{array}{l}\text { After deduction of firms with unrelated events to the } \\
\text { stock option plan exists. }\end{array}$ & 58 \\
\hline Final sample & 25 \\
\hline
\end{tabular}

Based on past studies, when examining the firm performance, the common performance measures are widely used such as stock market return, asset return and equity return (see Hall and Liebman, 1998; Abdelaziz, Amine and Lanour, 2011). In this study, estimating the effects of stock option plan on the level of firm performance follows Triki and UrecheRangau (2012) who use panel data that included the year of stock option grants, performance measures such as return on assets (ROA), return on equity (ROE) and Tobin'sQ. And also following Mehran (1995), Core, Holthausen and Larker (1999) and Hillegeist and Penalva (2003) the size of stock option is used in the formulated model. These studies employ multivariate regression analysis in which the previously mentioned accounting performance measures are calculated. Accordingly, the return on assets (ROA) is calculated with earnings before interest, tax and depreciation to total assets by percentage before and 
after stock option grants, while the return on equity (ROE) is set equal to net income before ordinary items divided stock option grants, and Tobin's $Q$ is the ratio market value of share capital to the book value of total assets following stock option grants. Note that Tobin's $Q$ measures whether the firm's market value is equal to replacement cost. If the ratio is greater than 1 , then it implies that the company's share is overvalued and vice-versa.

For explanatory variables employed include the size of grants corresponding to the number of stock option grants at the time of the board meeting date divided by the number of outstanding shares at the closest fiscal year. Since the expected effect of stock option grants may lead to improved firm efficiency through alleviation of the agency problem between managers and shareholders, firm performance can be expected to improve. It has been suggested that by isolating the consequences of the adoption of executive stock options and broad-based stock options that this produces advantages. However, the effects between the beneficial groups might differ because executive levels may have directly influence on firm decision-making behaviour. As a result, the prediction signs for ROA and ROE are expected to have a positive in the following year of stock option grants, while Tobin's $Q$ is expected to increase following the adoption of stock option plans, which can be expected to impact firm value.

For further additional variables in the regression equation to control for potential effects on firm performance. These control variables which are likely to influence the firm performance, then the sample are split into firm characteristics and event characteristics. The firm characteristics include leverage, the size of the firm and the growth of the firm growth. While the event characteristics proxy are by announcement types (first-time and seasonal) and beneficial or target groups (executive stock options or broad-based stock options).

The more specific control variables are a leverage variable equal to the log of total debt divided by total assets, which contends that high debt ratios might affect the firm's growth and therefore result in less firm specific profit. It is generally argued that firm with large debt tends to reduce the size of their stock option plan. From the debt holder's perspective, stock option plans are viewed as monitoring instruments used to keep an eye on management incentives to mislead free cash flows, which is expected to improve firm performance. The predicted sign for the coefficient of the impact of stock option plans on the leverage ratio can be expected to have both positive and negative effects. The second control variable, the size of the firm, is measured by the logarithm of total assets. Prior studies report the size of the firm an important predictor of stock option grants which is relevant to firm performance and is frequently observed as a major determinant in compensation pays.

Since larger size firms generate higher profits, as a result of benefit from economies of scale, it is argued that this not only provides greater opportunities to create internal funds but also access to external sources of finance for undertaking investment projects. Therefore, I would expect the size of the firm to have a positive on the adoption of stock option plans. The growth opportunity of the firm is measured by the log of market-to-book ratio, as many studies suggest that high growth opportunities frequently indicate higher firm performance. Firms with high growth opportunities tend to allocate a large fraction of stock options in order to enhance managerial efforts towards generating profitable projects, especially firms that operate in the highest volatile industry. From an agency theory perspective, firms with stock option plans are likely to implement them to reap the benefits from aligning the interests of employees and shareholders, which would also encourage managers to make 
better decisions to invest in highly profitable projects on behalf of shareholders. Therefore, the ratio $\mathrm{M} / \mathrm{B}$ is used to capture the incentive effects, which is expected to generate a positive sign for stock option plans.

In this study, the announcement of a stock option plan is represented by a dummy variable equal to 1 if the firm advertised the plan for the first-time, and 0 otherwise. The expected sign for this coefficient is expected to be positive, since the stock option plans granted to beneficiaries at the first-time of announcement can be expected to serve as an incentive for employees' thereby resulting in improved firm performances. Thus the sign of the coefficient is expected to be positive. The target group is also a dummy variable equal to 1 , if the firm allocates the stock option plan to employees and 0 otherwise. The coefficient sign is expected to be negative since employees are less directly influenced by firm specific factors designed to increase firm value.

In addition, the intra-industry differentiation of firms is an immediate concern, since stock option grants may reflect industry-based trends. In regard to this, the literature identifies industry membership as a key factor in broad-based stock option use which correlates to a firm's performance. In particularly, firms issuing stock options with an intensity of retaining talented and skilful employees are viewed as high priority, so too are firms involved in intensive research and development (R\&D) activities. Ittner, Lambert and Larker. (2003) argue that the retention of key employees is more crucial to technological firms and firms with a rapidly growing labour force. For this reason competition for employees among firms within the same industry is more volatile. Thus the granting of stock options might eliminate the necessity of adjusting salaries to reflect the state of the labour market. None the less, Oyer (2004) notes that firm value is still essential to determining the value of stock option-based pay packages. Accordingly, industry-adjusted performance measures for ROA, ROE and Tobin's $Q$ are measured three years after the announcement of a stock option plan.

Since the main purpose is to determine the effects of stock option plans on firm performance, the following performance production function:

$$
\text { Perfit }_{\text {it }}=\beta_{1 \mathrm{i}}+\beta_{2} X_{2 i t}+\beta_{2} X_{\text {ait }}+\beta_{4} X_{4 i t}+\beta_{5} X_{5 i t}+\beta_{6} X_{6 i t}+\beta_{7} X_{7 i t}+\mu_{\text {it }}+\varepsilon_{\text {it }}
$$

where $\operatorname{Perf} f_{i t}$ is the accounting performance measures for firm $i$ at $t$ time $(i=1, \ldots ., \mathrm{N} ; t=$ $1, \ldots ., \mathrm{T}), X_{1 i t}, X_{\text {2it }}, X_{3 i t}, X_{3 i t}, X_{4 i t}$ are respectively the size of stock option grant, leverage, firm size and growth of firm $i$ at $t$ time, and $X_{5 i t}$, and $X_{6 i t}$ are the respective dummy variables relating to announcement types and target groups, $\mu_{i t}$ represents firm-fixed effects, $\beta^{\prime}$ s are slope coefficients and $\varepsilon_{i t}$ is a disturbance term. A variety of specifications is estimated for the purpose of analysis using panel data of the announcement years of stock option grants. In the literature, this approach produces evidence of positive and negative performance outcomes associated with plan adoption decisions.

\section{Empirical results for Stock option Plan on firms' performance}

This section presents and discusses results relating to the long-term effects of stock option plans on firm performance for three years following the announcement of stock options. The study follows Yeo et al. (1999) by employing accounting performance measures such as the 
return on asset (ROA), the return on equity (ROE) and Tobin's Q. The reported median value measures operating performance, while industry-adjusted performance is used to control for industry effects. The analysis of the long-term effects of stock option plans on firm performance highlights the pattern of firm performance following the announcement of stock option plans, followed by an analysis linking firm characteristics and event characteristics. Table 1 shows the pattern of performance measures for a sample of firms and industry, including a summary of the unadjusted and industry-adjusted year-on-year changes in which t-1 (one year before the announcement of stock option plan) is chosen as the base period. The overall analysis covers five (5) accounting years, which includes $t-1$ to $t+$ 3 (three years before the announcement of stock option plans).

The overall results provide an unclear pattern in accounting performance measures following the announcement of stock option plans. Compared to the base period (year-1), the median firm change values are lower and weakly significant and suggest that the use of stock option plans by Malaysia-listed firms do not have a strong influence on firm performance. If anything, the findings suggest that listed firms with stock option plans do not increase operating performance. This particular observation is consistent with the findings of Yeo et al. (1999) who report no significant change in the performance of Singapore listed firms following the adoption of stock option plans. It is worth noting that the highest median changes observed in year-2, and the negative in year-3, indicate that the performance of firm's are not enhanced by the adoption of stock option plans but instead result in poorer firm performance. From the test results, the statistics for the median value is insignificant and suggest that awarding stock options do not entirely reflect a firm's performance. However, it is also noticeable that when the median to industry-adjusted change is replaced the results improve, since the number of positive median change is higher than the negative value. This therefore tells us that the use of stock option plans does have an effect on firm performance. For example, it is evident from the statistics that the industry-adjusted median changes from the base period of three fiscal years following the adoption of stock option plans are all positive. The result is somewhat inconsistent to earlier findings on the positive impact hypothesis in U.S. studies such as Larker (1983), Brickley, Bhagat and Lease (1985), Defusso, Johnson and Zorn (1990) and Cresson (2007). Consistent results on positive returns are also shown in European studies offering stock option plans (Langmann, 2007; and Thouraya and Ereche-Rangau, 2012).

Nevertheless, going on the basis of the conclusions of studies on Asian countries there are positive share market reactions to stock option plans (Yeo et al., 1999; Ding and Sun, 2001; and Kato et al. (2005). However, the first Malaysian study carried out by Obiyatulla et al. (2009) finds contrasting results between market reactions and the granting of stock option plans. However, the negative significant statistics for the median industry-adjusted change in ROA in year-3, as compared to the base period, indicate poor levels of profitability for the firms in our sample or that cash-strapped firms are likely to use stock options in place of cash pay. This particular result support the findings of Yermack (1995) and Core and Guay ( 2001), perhaps because the actual granting of stock options defer the impact of compensation on earnings since ROA reflects earnings before interest, tax, and depreciation to total assets. 
Table 1 Accounting performance measures of firms for three years before and three years after stock options plan adoption

\begin{tabular}{|c|c|c|c|c|}
\hline \multicolumn{5}{|c|}{ Results of the change in operating performance } \\
\hline & Year -1 to 0 & Year -1 to 1 & Year -1 to 2 & $\begin{array}{l}\text { Year }-1 \text { to year } \\
3\end{array}$ \\
\hline \multicolumn{5}{|l|}{ Return on assets } \\
\hline \multicolumn{5}{|l|}{ Firm median year- $1=4.1266$} \\
\hline \multicolumn{5}{|c|}{ Industry-adjusted median year $1=1.2226$} \\
\hline Median firms change & -0.031 & 0.804 & 1.234 & -0.367 \\
\hline Median industry-adjusted change & -0.285 & $-0.684^{*}$ & 0.378 & $-1.243^{* *}$ \\
\hline Number of Observations & 77 & 77 & 77 & 77 \\
\hline \multicolumn{5}{|l|}{ Return on equity } \\
\hline \multicolumn{5}{|l|}{ Firm median year $1=9.1479$} \\
\hline \multicolumn{5}{|c|}{ Industry-adjusted median year-1 = 1.5323} \\
\hline Median firm change & -0.217 & -0.539 & 1.380 & 0.182 \\
\hline Median industry-adjusted change & 0.88 & 0.81 & 1.49 & $2.11^{* *}$ \\
\hline Number of observations & 78 & 78 & 78 & 78 \\
\hline \multicolumn{5}{|l|}{ Tobins's Q } \\
\hline \multicolumn{5}{|c|}{ Firm median year $1=0.9961$} \\
\hline \multicolumn{5}{|c|}{ Industry-adjusted median year-1 $=-0.1148$} \\
\hline Median firms change & 0.011 & 0.023 & -0.003 & -0.076 \\
\hline Median industry-adjusted change & $0.149^{* * *}$ & $0.141^{* * *}$ & $0.045^{*}$ & 0.018 \\
\hline Number of observations & 77 & 77 & 77 & 77 \\
\hline \multicolumn{5}{|c|}{$\begin{array}{l}\text { This table indicates the change in the accounting performance measures of firms represented by return on assets } \\
\text { (ROA), return on equity (ROE) and Tobin's } Q \text { from the one year before stock option plan announcement (year-1). } \\
\text { Year } 0 \text { is the fiscal year in which the stock option plan is announced. The significance levels are based on the } \\
\text { Wilcoxon signed rank test. *** and }{ }^{* * *} \text { describe statistical significance at the } 90,95 \text { and } 99 \% \text { levels, respectively. }\end{array}$} \\
\hline
\end{tabular}

The literature on stock options plans provides evidence which strongly suggests that firm level characteristics and event characteristics may have a potential effect on the long-term performance of firms. The results for both firm characteristics and event characteristics are displayed in Table 2. The overall results, reported in Panel A, indicate positive statistical mean for all performance measures prior to and following the adoption of stock option plans. For example, following the adoption of stock option plans the mean values for both ROA and ROE increase, suggesting that Malaysian firms are optimistic that the adoption of stock option plans will result in improvement in corporate performance. Panel B indicates that when linked to event and firm characteristics that on average firms with stock option plans issued 11,258,668 shares following plan approval, which is approximately 7 per cent of outstanding shares. It is noticeable that the standard deviations for most characteristics are relatively high which also indicate the significance of observed factors influencing firm performance. 
Table 2 Average levels for three years before adoptions and three years after plan adoptions

\begin{tabular}{|c|c|c|c|c|c|c|c|c|c|c|c|c|c|c|c|}
\hline \multirow[t]{2}{*}{ Variable } & \multicolumn{5}{|c|}{ Before } & \multicolumn{5}{|c|}{ Grant } & \multicolumn{5}{|c|}{ After } \\
\hline & $\mathrm{N}$ & Mean & $\mathrm{Sd}$ & Min & Max & $\mathrm{N}$ & Mean & $\mathrm{Sd}$ & Min & Max & $\mathrm{N}$ & Mean & $\mathrm{Sd}$ & Min & Max \\
\hline \multicolumn{16}{|c|}{ Panel A :Performance measures } \\
\hline $\mathrm{ROA}$ & 227 & 1.72 & 1.27 & -3.47 & 5.09 & & & & & & 249 & 1.89 & 1.20 & -2.75 & 4.58 \\
\hline ROE & 227 & 1.05 & 1.16 & -4.25 & 3.30 & & & & & & 249 & 1.25 & 1.16 & -3.18 & 3.88 \\
\hline $\begin{array}{l}\text { TOBIN'S } \\
Q\end{array}$ & 227 & 0.10 & 0.39 & 0.02 & 2.40 & & & & & & 249 & 0.05 & 0.40 & -0.82 & 2.06 \\
\hline \multicolumn{16}{|c|}{ Panel B :Event characteristics and Firm characteristics } \\
\hline Grant $(\mathrm{N})$ & & & & & & 83 & $11,258,668$ & $12,278,164$ & 477,150 & $52,590,000$ & & & & & \\
\hline Size $(\%)$ & & & & & & 83 & 7.94 & 6.14 & 0.21 & 44.15 & & & & & \\
\hline Leverage & 227 & 2.92 & 1.36 & -3.54 & 5.91 & & & & & & 249 & 2.77 & 1.21 & -2.36 & 4.61 \\
\hline Size & 227 & 5.79 & 1.31 & 1.99 & 9.27 & & & & & & 249 & 6.12 & 1.38 & 3.19 & 10.27 \\
\hline Growth & 227 & 0.05 & 0.66 & -2.09 & 2.48 & & & & & & 249 & -0.01 & 0.76 & -1.75 & 4.08 \\
\hline
\end{tabular}




\section{The long-term effects of stock option grants on firm performance}

Table 3 displays the results for the fixed effects model for performance measures and stock option grants. Panel A shows the results based on the raw performance measures, while Panel B summarises the findings of industry-adjusted performance measures. Each column corresponds to specifications for the long-term effects of ROA, ROE and Tobin's-Q to stock option grants. The equation for the fixed effect models are as follows:

Perf $_{\text {it }}=\beta_{0}+\beta_{1_{1} \text { grant }_{i t}}+\beta_{2}$ lev $_{\text {it }}+\beta_{3}$ size $_{\text {it }}+\beta_{4}$ growth $_{\text {it }}+\beta_{5 \text { ann }}$ it $+\beta_{6}$ tg $_{\text {it }}+\mu_{\text {it }}+\varepsilon_{\text {it }}$

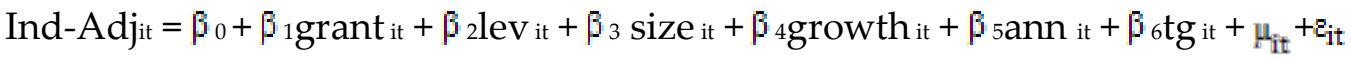

where $\operatorname{Perf}_{i t}$ and Ind $-A d j_{i t}$ are the accounting performance measures and industryadjusted measures for firm $i$ at $t$ time $(i=1, \ldots ., \mathrm{N} ; t=1, \ldots ., \mathrm{T}), X_{1 i t}, X_{2 i t}, X_{3 i t}, X_{3 i t}, X_{4 i t}$ are respectively the size of stock option grant, leverage, firm size and growth of firm $i$ at $t$ time, and $X_{5 i t}$ and $X_{6 i t}$ are the respective dummy variables relating to announcement types and target groups, $\mu_{i t}$ represents firm-fixed effects, $\beta^{\prime}$ s are slope coefficients and $\varepsilon_{i t}$ is a disturbance term

Results of the first specification in Panel A for ROA produces $\mathrm{R}^{2}$ value $=0.4752, \mathrm{~F}=86.62$, with $\mathrm{p}=0.00$. The second specification, using the performance variable of ROE, reveals $\mathrm{R}^{2}$ value $=0.5824, F=7.210540$ with $p=0.00$ and Tobin's $Q$ generates $R^{2}$ value $=0.4569, F=$ 4.3490 with $\mathrm{p}=0.00$. The generated $\mathrm{R}^{2}$ values in the fixed model indicate that 48 per cent of the independent variables can be explained the dependent variable of ROA, which is 47 percent for ROE and 46 percent for Tobin's-Q.

The overall results, using the raw performance measures, show the grant size coefficient to be positive. However, the column indicates that the ROA model generates significant interaction, while the columns for ROE and Tobin's-Q report a weak association, indicating evidence that stock option size does not lead to increased firm performance levels. Prior studies reveal the variables of firm characteristics and event characteristics as generating potential effects in influencing the firm's decision to establish stock option plans. The test results relating to firm characteristics show the prediction signs are fulfilled and strongly significant. Particularly, the three independent variables of leverage, firm size and firm growth are significantly related to all performance measures at the 1 and 5 percent levels. In contrast to the variables of event characteristics, the overall coefficients are found to be weakly significant except the target groups in ROA model show a strong interaction. It is noted that non-significant variables in event characteristics closely related to stock option grants, authenticating first-time announcements, do not lead to a firm's improvement in performance. The findings also indicate that stock option grants do not entirely benefiting employees.

Since the overall results in panel A revealed weak performance effects among Malaysian firms with stock option plans, all regressions were rerun using adjusted accounting performance measures. The industry-adjusted performance measures are examined for three (3) years after the stock option plans have been established with no changes in the firm and event characteristics. The findings of Panel B are included in Table 4 for the purpose of comparison only. At first glance, the regression results in Panel $\mathrm{B}$ show that $\mathrm{R}^{2}$ values are lower when using the raw performance measures, while the industry-adjusted fixed effects 
models produced an $\mathrm{R}^{2}$ of $0.26, \mathrm{~F}=1.8157$ with $\mathrm{p}=0.00$, an $\mathrm{R}^{2}$ of $0.28, \mathrm{~F}=2.0136$ with $\mathrm{p}=0.00$ for ADJROA and ADJROE, respectively. The highest generated $\mathrm{R}^{2}$ is for ADJTQ of 0.44, $\mathrm{F}=3.992390$ with $\mathrm{p}=0.00$. The results indicate that all independent variables are explained as 26, 28 and 44 per cent for the dependent variables ADJROA, ADJROE and ADJTQ, respectively.

The regression coefficient values for grant size are found to be insignificant. The weak evidence suggests the industry membership of firms with stock option plans are not reflected exclusively on account of industry-based trends. Prior studies in this area strongly suggest that technology or R\&D based firms adopt more stock options for retaining or attracting skilful staffs; however, the negative impact for industry-adjusted ROA provides little support to this conclusion. When industry-adjusted specifications are extended with firm characteristics, it is found that the coefficients of firm growth is positive and highly significant in the ADJROA $(\beta=0.171062)$, ADJROE $(\beta=0.207232)$ and ADJTQ $(\beta=0.164505)$. In addition, all variables of event characteristics have non-significant effects on a firm's performance, except the leverage ratio which is found to have a significant coefficient value in the industry-adjusted Tobin's Q. Similar patterns are reported for event characteristics using raw performance measures in which all variables are shown to have non-significant coefficient values.

Table 3 provides a summary of the results relating to the effects of stock option plans on return on assets (ROA), return on equity (ROE) and Tobin's-Q. The statistics show that there are no differences in results using raw performance or industry-adjusted measures, since all performance measures are not significant with stock option grants. The results provide little evidence of the existence of an association between stock option grants and firm performance levels. In particular, the characteristics of firms with stock option plans generating results based on raw performance measures strongly authenticated the study's arguments. However, the findings of using industry-adjusted performance measures provide less support to the study's conclusions.

The variables represent that event characteristics construct similar patterns, resulting from non-significant relationships to firms' performance, which suggests that additional characteristics of stock option plans do not lead to improvements in firm performance. Thus the non-significant effects of the models might be a direct result of mis-specification in the estimator. Therefore, the use Hausman statistical test, which is more rigorous, to address the issue. The purpose of Hausman test is to determine no mis-specification exists in the estimator based on its differences with the random effects estimator. The results reported in Table 3 show that the test statistic of ROA is 79.4618 with p-value of 0.000 ; ROE is 45.7269 with p-value of 0.000 and Tobin's-Q is 21.1451 with p-value of 0.000 . Thus it may be concluded that there is a difference between random effects and fixed effects models with fixed effects models being better estimators for determining the long-term performance effects on stock option grants. The analysis for all specifications and stock option plans closely follows the fixed effects estimator. Similar to the test employed in the sample reported in Panel A, the Hausman tests for Panel B reports contrasting results. Two out of three specifications show there are mis-specifications in the fixed effects estimator, based on its differences with the random effects estimator. And this suggests that random effects estimators for industry-adjusted ROA and ROE are better. 
Table 4 Summary of results for return on assets (ROA), return on equity (ROE) and Tobin's-Q for stock option plan adoption

\begin{tabular}{|c|c|c|c|c|c|c|c|}
\hline \multicolumn{8}{|c|}{ Fixed Effects Panel Model } \\
\hline & & \multicolumn{3}{|l|}{ PANEL A } & \multicolumn{3}{|l|}{ PANEL B } \\
\hline & & 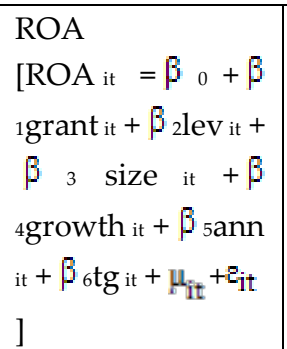 & 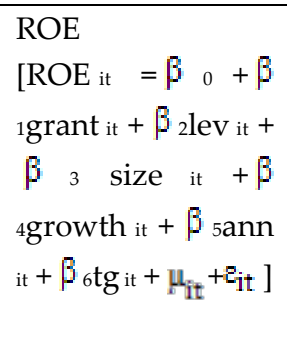 & 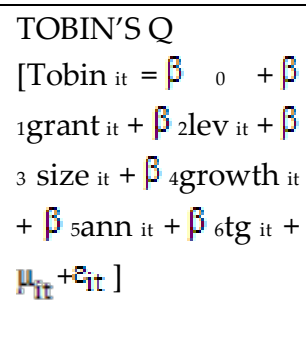 & 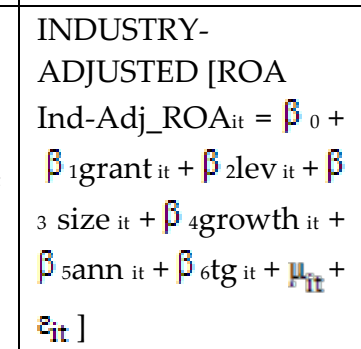 & 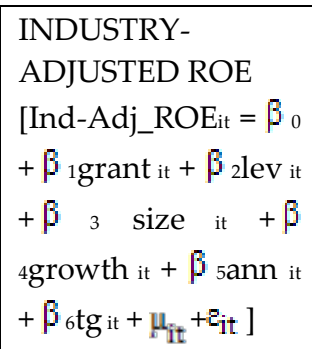 & 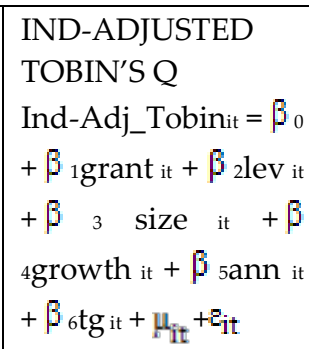 \\
\hline $\begin{array}{l}\text { Explanatory } \\
\text { Variables }\end{array}$ & $\begin{array}{l}\text { Prediction } \\
\text { sign }\end{array}$ & & & & & & \\
\hline Constant & & -0.364398 & 0.442756 & -0.022636 & -0.249465 & -0.230194 & -0.011014 \\
\hline Grant size & + & $0.480902^{* * *}$ & 0.046534 & 0.032965 & -0.022719 & 0.005674 & 0.036992 \\
\hline \multicolumn{8}{|c|}{ Firm-characteristics } \\
\hline Leverage & $?$ & $-0.082609^{* * *}$ & $-0.081094^{* *}$ & $0.045029^{* * *}$ & -0.030517 & -0.059710 & $0.042315^{* * *}$ \\
\hline Size & + & $0.147763^{* * *}$ & $0.081356^{* *}$ & -0.012740 & 0.043316 & 0.057107 & -0.012234 \\
\hline Growth & + & $0.178934^{* * *}$ & $0.205801^{* * *}$ & $0.186091^{* * *}$ & $0.171062^{* * *}$ & $0.207232^{* * *}$ & $0.164505^{* * *}$ \\
\hline \multicolumn{8}{|c|}{ Event-characteristics } \\
\hline Announcement & + & -0.221166 & -0.182302 & -0.041228 & -0.056712 & 0.000827 & -0.069726 \\
\hline Target groups & - & $1.471465^{* * *}$ & -0.238750 & 0.012684 & -0.041544 & 0.000280 & 0.025143 \\
\hline $\mathrm{R}^{2}$ & & 0.475191 & 0.582399 & 0.456868 & 0.259917 & 0.280717 & 0.435727 \\
\hline F-value & & $86.62177^{* * *}$ & $7.210540^{* * *}$ & $4.349048^{* * *}$ & $1.815780^{* * *}$ & $2.013642^{* * *}$ & $3.992390^{* * *}$ \\
\hline Durbin-Watson & & 1.178232 & 1.514217 & 1.383540 & 1.651807 & 1.513619 & 1.353487 \\
\hline Firm & & 83 & 83 & 83 & 83 & 83 & 83 \\
\hline Data point & & 581 & 581 & 581 & 581 & 581 & 581 \\
\hline Hausman Test & & $79.4618^{* * *}$ & $45.7269^{* * *}$ & $21.1451^{* * *}$ & $11.1144^{*}$ & 4.9341 & $21.0462^{* * *}$ \\
\hline \multicolumn{8}{|c|}{$\begin{array}{l}\text { The reported results employ a fixed effect model. The dependent variables are return on assets (ROA), return on equity (ROE) Tobin's-Q (TQ) and industry-adjusted } \\
\text { Tobin's-Q (ADJTQ). Both dependent variables are measured three years after stock option plans were established. Grant size is equal to the number of stock option } \\
\text { grants at the time of announcement (EGM date), divided by the number of outstanding shares at the closest fiscal year. Leverage is equal to the firm's total debt divided } \\
\text { by the total assets. Firm size is measured by the log of total assets value. Growth opportunity is calculated based on market to book ratio (M/B ratio) is calculated the } \\
\text { company's market capitalization divided with the company's total book value. Target group is a dummy variable, which is equal to } 1 \text {, if the stock options are provided to } \\
\text { employees, } 0 \text { otherwise. }{ }^{* * *} \text { and }{ }^{* * *} \text { illustrate significance levels at the } 90,95 \text { and } 99 \% \text {, respectively. P-value in parenthesis. }\end{array}$} \\
\hline
\end{tabular}




\section{Concluding Remarks}

For the long-term effect, stock option plans do not entirely lead to improvements over firm value in Malaysia, as the results indicate no significant effects on long-term firm performance. In fact, based on the study's results, stock option grant's size does not lead to good share performance. These findings may however spur debate about the role stock option plans play in enhancing firm performance and as mentioned earlier, in the few years that stock options have been in use in Malaysia, stock option plans gained popularity. But at the same time manipulation in accounting measures and stock prices such as creative accounting and earnings management, led the public to question the practicality in adopting stock option plans at least for reducing agency problems. From the results also emphasise that stock option plans might contribute to manipulation in accounting measures is likely to be a cause of public concern. Therefore, this makes up the relevant groups and so a minority watchdog group should be called upon to monitor any decisions related to the adoption of stock options and executive's remuneration. The relevant authority such as Bursa Malaysia and Malaysia Securities of Commission (SC) should also seek a mechanism that would provide external parties to monitor and check on executive's remuneration especially in firms with high concentrated shareholdings. This includes the rule pertaining to stock option plans which should be revised to reflect the concern brought up by this study.

\section{References}

Abdelaziz, E.M., Amine, L., \& Lanour, C. (2011). Stock options and the performance of CAC40 listed companies. International Journal of Economics and Finance, 3(1), 218-228.

Abdul Rahman, R., \& Mohamed Ali, F.H. (2006). Board, audit committee, culture and earnings management: Malaysian evidence. Managerial Auditing Journal, 21(7), 783-804.

Aboody, D. (1996). Market valuation of employee stock options. Journal of Accounting and Economics, 22, 357-391.

Aboody, D., \& Kasznik, R. (2000). CEO stock option awards and the timing of corporate voluntary disclosures. Journal of Accounting and Economics, 29, 73-100.

Anderson, R.C., \& Reeb, D.M. (2003). Founding-family ownership and firm performance: Evidence from the S\&P 500. The Journal of Finance 58(3), 1301-1327.

Ariff, M., Shamsher, M., \& Nasir, A.M. (1998). Stock pricing in Malaysia: Corporate financial and investment management. Universiti Putra Malaysia Press: Serdang.

Bebchuk, L., \& Fried, J. (2003). Executive compensation as an agency problem. Journal of Economic Perspectives, 17, 71-92.

Bebchuk, L., \& Grinstein, Y. (2005). The growth of executive pay. Oxford Review of Economic Policy, 21(2), 283-303.

Beiner, S., Drobetz,W., Schmid, F. \& Zimmermann, H. (2004). Is board size an independent corporate governance mechanism? Kyklos, 57, 327-356.

Bettis, J.C., Bizjak, J.M., \& Lemmon, M.L. (2005). Exercise behaviour, valuation and the incentive effects of employee stock options. Journal of Financial Economics 76(2). 445-470.

Bhagat, S., \& Black, B.S. (2001). The non-correlation between board independence and long-term firm performance. Journal of Corporation Law, 27,231-274.

Black, B.S., Jang, H., \& Kim, W. (2002). Does Corporate Governance Affect Firm value? Evidence from Korea (Working Paper No.237). Standford Law School.

Blasi, J., Freeman, R., Mackin, C., \& Keuse, D. (2010). Creating a bigger pie? The effects of employee ownership, profit sharing and stock options on workplace performance, shared capitalism at work: employee ownership, profit and gain sharing and broad-based stock options. Doughlas Kruse, Richard Freeman and Joseph Blasi (Ed.). Chicago: University of Chicago Press. 
Brickley, J., Bhagat, S. \& Lease, R. (1985). The impact of long-range managerial compensation plans on shareholder wealth. Journal of Accounting and Economics, 115-129,

Brook, C. (2008). Introductory Econometrics for Finance (2nd Edn). Cambridge: UK

Brown, S., \& Warner, J. (1985). Using daily stock returns: The case of event studies. Journal of Financial Economics, 14, 3-31.

Bulan, L.P., Sanyal, P., \& Yan, Z. (2010). A few bad apples: An analysis of CEO performance pay and firm productivity. Journal of Economics and Business, 62, 273-306.

Bushman, R. M., \& Indjejikian, R. J. (1993). Accounting income, stock price, and managerial compensation. Journal of Accounting and Economics, 16(1-3), 3-23.

Carpenter, J.N. (1998). The exercise and valuation of executive stock option. Journal of Financial Economics, 48, 127158.

Cheung, Y.L., Rau, P.R. \& Stouraitis, A. (2006). Tunnelling, propping and expropriation: evidence from connected party transactions in Hong Kong. Journal of Financial Economics 82,343-386.

Chourou, L., Abaoub, E., \& Saadi, S. (2008). The economic determinants of CEO stock option compensation. Journal of Multinational Financial Management, 18(1), 61-77.

Claessens, S., Djankov, S., \& Lang, L.H.P. (2000). The separation of ownership and control in East Asian Corporations. Journal of Financial Economics, 58, 81-112.

Cohen, J.W. (1988). Statistical power analysis for the behavioral sciences (2nd edn). Hillsdale, NJ: Lawrence Erlbaum Associates.

Cohen, R. B., Hall B. J., \& Viceira, L. M. (2000), Do Executive Stock Options Encourage Risk- Taking? (Working Paper). Harvard Business School.

Coles, J.L., Daniel, N.D., \& Naveen, L. (2005). Boards: Does one size fit all? (Working paper). Arizona State University.

Conyon, M.J., \& Leech, D. (1994). Top pay, company performance and Corporate Governance. Oxford Bulletin of Economics and Statistics, 56 (3), 229-247.

Core, J., Holthausen, R., \& Larker, D. (1999). Corporate governance, chief executive officer compensation and firm performance. Journal of Financial Economics, 51, 371-406.

Core J.E., \& Guay, W.R. (2001). Stock option plans for non-executive employees. Journal of Financial Economics, 61 (2). 253-287.

Cosh, A., \& Hudges, A. (1997). Executive remuneration, executive dismissal and institutional shareholdings. International Journal of Industrial Organization, 15, 469-492.

Coughlan, A., \& Schmidt, R. (1985). Executive compensation, management turnover and firm performance. Journal of Accounting and Economics, 7 (1-3),43-66.

Dechow, P.M., Sloan, R.G., \& Sweeney, A.P. (1996). Causes and consequences of earnings manipulation: An analysis of firms subject to enforcement actions by the SEC. Contemporary Accounting Research, 13, 1-36.

Defond, M.L., \& Hung, M. (2004). Investor protection and corporate governance: Evidence from Worldwide CEO Turnover. Journal of Accounting Research, 42(2), 269-312.

DeFusco. R., Johnson, R., \& Zorn, T. J. (1990). The effect of executive stock option plans on stockholders and bondholders. Journal of Finance, 45(2), 617-627.

Ding, D.K., \& Sun, Q. (2001), Causes and effect of stock option plans: Evidences from Singapore, Pacific-Basin Finance Journal, 9, 563-599.

Duffhues, P., Kabir, R., Mertens, G., \& Roosenboom, P. (2003). Employee stock option grants and firm performance in the Netherlands. Bedrijsskunde, 75, 667-678.

Duffhues P., \& Kabir, R. (2008). Is the pay-performance relationship always positive? Evidence from the Netherlands. Journal of Multinational Financial Management, 1, 45-60.

Fich, E., \& Shivdasani, A. J. (2005). The impact of stock-option compensation for outside directors on firm value. Journal of Business, 78 (6), 2229-2254.

Gaver, J., \& Gaver, K. (1993). Additional evidence on the association between the investment opportunity set and corporate financing, dividend, and compensation policies. Journal of Accounting and economics, 16, 125-160.

Gerety, M., Hoi, C. K., \& Robin, A. (2001). Do shareholders benefit from the adoption of incentive pay for directors? Financial Management, 30, 45-61.

Gibson, M.S. (2003). Is corporate governance ineffective in emerging market? Journal of Financial and Quantitative Analysis, 38, 231-250.

Hafiza Aishah, H. \& Susela D. (2009). Board characteristics, ownership structure and earnings quality: Malaysian evidence. Research in Accounting in Emerging Economies 8, 97 - 123. 
Haleblian, J., \& Finkelstein, S. (1993). Top management team size, CEO dominance, and firm performance: The moderating roles of environmental turbulence and discretion. The Academy of Management Journal, 36 (4), 844 863.

Hanlon, M., Rajgopal, S., \& Shevlin, T.J. (2003). Are executive stock options associated with future earnings? Journal of Accounting and Economics, 36 (1-3), 3-43.

Haniffa, R.M., \& Cooke, T.E. (2002). Culture corporate governance and disclosure in Malaysian corporations. Abacus, 38,317-349.

Haniffa, R.M., \& Hudaib, M. (2006). Corporate governance structure and performance of Malaysian listed companies. Journal of Business Finance and Accounting, 33 (7-8), 1034-1062.

Harrel, F.E. (2001). Regression Model Strategies: With Application to Linear Models, Logistic Regression and Survival Analysis. USA: Springer.

Hassan, H., \& Hoshino, Y. (2007). The performance impacts of stock options in Japan. Japanese Journal of Administrative Science, 20, 27-41.

Hillegeist, S. A., \& Penalva, F. (2004). Stock Option incentives and firm performance (Working Paper No 535). IESE Business School, University of Navarra.

Hochberg, Y., \& Linsey, L. (2010). Incentive, targeting and firm performance: An Analysis of Non-executive stock options: An Analysis of non-executive stock options. Review of Financial Studies, 23, 4148-4186.

How, J., Jelic, R., Saadouni, B., \& Verhoeven, P. (2007). Share allocations and performance of KLSE second board IPOs. Pacific-Basin Finance Journal, 15(3), 292-314.

Hutchinson, M. (2003). An analysis of the association between firm risk, executive share options and accounting performance: some Australian evidence. Review of Accounting and Finance, 2 (3), 48 - 71.

Jensen, M.C., \& Meckling, W.H. (1976). Theory of the firm: managerial behaviour, agency costs and ownership structure. Journal of Financial Economics, 3(4), 305-360.

Kahle, K. M., \& Shastri, K. (2005). Firm performance, capital structure, and the tax benefits of employee stock options. Journal of Financial and Quantitative Analysis, 40(1), 135-160.

Kang, J. K., \& Shivdani, A. (1996). Does the Japanese governance system enhance shareholder wealth? Evidence from the stock price effects of top management turnover. The Review of Financial Studies, 9, 1061-1095.

Kang, J.K. (2002). Handbook on company secretarial practice in Malaysia (3rd Edition). Kuala Lumpur: Lexis Nexis Business Solutions.

Kaplan, S.N. (1994). Top executive rewards and firm performance: A comparison of Japan and the United States. Journal of Political Economy, 102 (3), 510-546.

Kaplan S.N. \& Minton, B.A. (2008). How has CEO turnover changed? Increasingly performance sensitive boards and increasingly uneasy CEOs (NBER Working Papers 12465). National Bureau of Economic Research.

Kato, H.K., Lemmon, M., Luo, M., \& Schallheim, J. (2005). An empirical examination of the costs and benefits of executive stock options: Evidence from Japan. Journal of Financial Economics, 78(2), 435-461.

Kedia S., \& Mozumdar, A. (2002). Performance impact of employee stock options retrieval in http://ssrn.com/abstract=384188. AFA 2003 Washington D.C. Meetings

Klein, A. (2002). Audit Committee, Board of Director Characteristics, and earnings management. Journal of Accounting and Economics, 33 ( 3 ), 375-400.

Kim, N. J. (1990). Do long-term incentive plans matter? Business Forum, 15(2), 15.

Kole, S. (1997). The complexity of compensation contracts. Journal of Financial Economics, 43(1). 79-104.

Lambert, R., Larcker, D., \& Verrecchia, R. (1991). Portfolio considerations in valuing executive compensation. Journal of Accounting Research, 29, 129-149.

Landsman, W., Lang, M., \& Yeh, S. (2007). Governance and the Split of Options between Executive and Nonexecutive Employees. Journal of Accounting Auditing and Finance, 22 (2), 109-138.

Langmann, C. (2007). Stock Market Reaction and Stock Option Plans: Evidence from Germany. SBR (59), 85-106.

La Porta, R., De-Silanes, F.I., \& Shleifer, A. (1999). Corporate ownership around the world. Journal of Finance LIV (2), 471-517.

Larker, D.F. (1983). The association between performance plan adoption and corporate capital investment. Journal of Accounting and Economics, 5, 3-30.

Lausten, M. (2002). CEO turnover, firm performance and corporate governance: Empirical evidence on Danish firms. International Journal of Industrial Organization, 20, 319-414.

Lehman, E.L. (1975). Nonparametrics: Statistical Methods Based On Ranks. Holden-Day: San Francisco.

Leonhardt, D. (April 19, 2000). Technology share downturn diminishing stock options. The New York Times, p.C1.

Lie, E. (2005). On the Timing of CEO Stock Option Awards. Management Science 51 (5), 802-812. 
Lipton, M., \& Lorsch, J.W. (1992).A modest proposal for improved corporate governance. Business Lawyer 48, 59-77.

Ittner, C.D., Lambert, R.A., \& Larcker, D. F. (2003). The structure and performance consequences of equity grants to employees of new economy firms. Journal of Accounting and Economics, 3, 89-127.

Mehran, H. (1995). Executive compensation structure, ownership and firm performance. Journal of Financial Economics, 38, 163-184.

Morck, R., Shleifer, A. \& Vishny, R.W. (1989). Alternative mechanisms for corporate control. The American Economic Review, 79 (4), 842-52.

Moscu, R.G. (2013). Does CEO duality really affect corporate performance? International Journal of Academic Research in Economics and Management Science, 2(1), 156-166.

Nagaoka, S. (2005). Determinants of the introduction of stock options by Japanese firms: Analysis from the incentive and selection perspectives. Journal of Business, 78 (6), 2289-2315.

Obiyathulla, I. B., Sharifah Raihan S, M. Z., Mohd Eskandar S.M.R. \& Azhar M. 2009. Granting employee stock options (ESOs), market reaction and firm performance. Asian Academy of Management Journal of Accounting and Finance, 5 (1), 117-138.

Oyer, P. (2004). Why do firms use incentives that have no incentive effects? The Journal of Finance, 59(4), 16191649.

Ozkan, N. (2009). CEO compensation and firm performance: An empirical investigation of UK panel data. European Financial Management, 17,260-285

Pallant, J. (2011). SPSS Survival Manual: A Step by step guide to data analysis using SPSS. McGraw-Hill International: NSW, Australia.

Pandher, G.S. (2003). Valuation of stock option grants under multiple severance risks. Journal of Derivatives 11(2).25-37.

Rajgopal, S., \& Shevlin, T. (2002). Empirical evidence on the relation between stock option compensation and risk taking. Journal of Accounting and Economics, 33(2), 145-171.

Renneboog, L. (2000). Ownership, managerial control and the governance of companies listed on the Brussels stock exchange. Journal of Banking and Finance, 24, 1959-1995

Rubinstein, M. (1995). On the accounting valuation of employee stock options. Journal of Derivatives, 3(1), 8-24.

Salsiah, M.A., Norman, M.S., \& Mohamat, S.H. (2008). Ownership structure and earnings management in Malaysian listed companies: the size effect. Asian Journal of Business and Accounting 1(2), 89-116

Samsa, M.K. \& Scheidt, K.S. (2003). International Employee Equity Plans: Participation beyond Border. The Hague: Kluwer Law International.

Sanders, W. G. (2001). Behavioral responses of CEO's to stock ownership and stock option pay. Academy of Management Journal, 44, 477-492.

Sanders, W.M. G., \& Hambrick. D.C. (2007). Swinging for the fences: The effects of CEO stock options on company risk taking and performance. Academy of Management Journal 50, 1055-1078.

Sharma, K. (2006). Understanding employee stock options. Global Business Revie, 7 (1), 77-93.

Sesil, J.C., Kroumova, M.K., Blasi, J.R., \& Kruse, D. L. (2002). Broad-based employee stock options in U.S. New economy firms. British Journal of Industrial Relations, 40(2). 273-294.

Smith, G.S., \& Swan, P.L. (2008). The road to riches: CEO incentives and firm performance. Retrieved at SSRN: http://ssrn.com/abstract $=1089968$

Triki, T., \& Ureche-Rangau, L. (2012). Stock options and firm performance: New evidence from the French Market. Journal of International Financial Management and Accounting, 23 (2), 154-185.

Wan Hussain W.N. (2009). The impact of family-firm structure and board composition on corporate transparency: evidence based on segment disclosures in Malaysia. The International Journal of Accountin, 44 (4), 313-333.

Yeo, G. H. H., Chen, S. S., Ho, K. W., \& Lee, C. (1999). Effects of executive share option plans on shareholder wealth and firm performance: The Singapore evidence. Financial Review, 34(2), 1-20.

Yermack, D. (1996). Higher market valuation of companies with a small board of directors. Journal of Financial Economics, 20, 185-213.

Zahiruddin, G. \& Fauziah, M.T. (2012). Effective interest alignment mechanism or tool to expropriate: A review of Malaysian ESOS Adoption, Malaysian Management Journal 16, 59-74. 
Journal of Contemporary Issues and Thought

Vol. 7, 2017 (104-118) 
